\title{
The Growth of the Megachurch
}

\author{
David E. Eagle
}

\section{$1 \quad$ Introduction $^{1}$}

The dominant view of megachurches claims they represent a new religious form, born in the United States in the 1970s and 8os. Contrary to this position, I argue megachurches enjoy a long history in Protestantism. An important example from the sixteenth century Huguenot architect Jacques Perret reveals an early Protestant vision for a large, multi-functional worship space. Soon after, this vision became realised in bricks and mortar. Revivalism and the Institutional Church Movement of the nineteenth and early twentieth centuries provide further connections between present-day megachurches and the past. Revivalism provided the motivation for Protestants to go out and reach the masses, and the Institutional Church Movement provided the infrastructure to attract, convert, and nurture them. The demographic shifts that occurred following WwII led to the proliferation of churches in post-war America. This meant that large churches became increasingly visible, but journalists and social commentators mistook their increase in prevalence for lack of historical precedent. Pastors and other leaders, capitalising on the appeal of innovation, reinforced this view. I offer an important corrective that helps situate megachurches in the United States in their proper context.

The megachurch burst into the American consciousness in the 1980s. Megachurches differed from their predecessors by offering their participants a single organisation to meet their spiritual, emotional, educational, and recreational

1 This chapter is adapted from the article Eagle, D.E. 2015. "Historicizing the Megachurch." Journal of Social History. 48:3, 589-604. The author extends deepest thanks to Mark Chaves, who provided the original impetus behind this research. Thanks are also due to Grant Wacker for his help and support to a sociologist posing as an historian, to Soon-Cha Rha for his helpful comments, and to Glenda LaCoste of Document Delivery Services for assistance tracking down primary source documents. 
needs. In 1989, the vanguard of the megachurch movement, 37 year-old Bill Hybels, said, "We're on the verge of making kingdom history.... doing things a new way for a whole new generation" (Chandler 1989). A 33 year-old Rick Warren, pastor of the then 5,000 member (now 20,000+ member) Saddleback Community Church echoed similar sentiments:

There's a trend all across America moving away from the small neighborhood churches to larger regional-type churches. It's the same phenomenon with malls replacing the mom and pop stores on the corner. People will drive past all kinds of little shopping centers to go to a major mall, where there are lots of services and where they meet their needs. The same is true in churches today in that people drive past dozens of little churches to go to a larger church which offers more services and special programs.

CHANDLER 1989

Writing in Christianity Today, Lyle Schaller, a prominent evangelical spokesman for the megachurch movement, proclaimed, "The emergence of the 'megachurch' is the most important development of modern Christian history. You can be sentimental about the small congregation, like the small corner grocery store or small drugstore, but they simply can't meet the expectations that people carry with them today" (Schaller 1990). This echoes the well-known marketing consultant Peter Drucker's claim that megachurches "are surely the most important social phenomenon in American society in the last 30 years" (quoted in Thumma and Travis 2007:1).

Several historians agree that megachurches lack precedent. Take Patrick Allitt. He sees them as an innovation of post-wwII America. "America's new megachurches", he argues " ....were designed to provide an entire way of life, including schools, gymnasiums, dining halls, study groups settings, therapy sessions, aerobics classes, bowling alleys, and sometimes even Christianthemed shopping" (Allitt 2003: 227). "Megachurch," Martin Marty says simply, "is.... an invention of the Age of Greed" (Marty 1990: 919).

Critics of the megachurch followed a similar line. Gustav Niebuhr, grandson of the famous theologian H. Richard Niebuhr, and long-time religion writer for the Wall Street Journal and New York Times, summarises their emergence as follows, "A shift of power and influence is slowly, but profoundly, changing the way many of the nation's 80 million Protestants worship. Since the 1980 , megachurches have gathered tens of thousands of worshipers into their folds and millions of dollars into their collection plates, becoming in the process 
new centers of Protestant influence" (Niebuhr 1995). In her biting 1984 critique of fundamentalist culture Carol Flake writes, "By the beginning of the eighties, the Lord's business had become big business.... The phantom congregations of the nation's TV preachers had become rooted in elaborate institutions and ordinary churches had grown into Super Churches" (Flake 1984: 49). With a similar axe to grind, William MacNair states:

In the panorama of religious events in the United States, the mega-church is something new. Nothing quite like it has appear before. True enough, it did have precursors.... But.... these very large mega-churches are a 'new kid on the block' among religious organizations in the United States.

MCNAIR 2009

In this article, I demonstrate that it is wrong to consider megachurches a new organisational form that emerged in the 1970s. Even though arguments in support of the novelty of the modern megachurch receive near-universal endorsement, a careful analysis reveals that megachurches are nothing new. The modern megachurch has emerged through a long process of evolution. The megachurch movement of the 1970 and 1980 s has roots that tap deep into the soil of Protestant religion - especially, but not exclusively, in revivalism and the Institutional Church Movement of the nineteenth and early twentieth centuries (Chaves 2006; Kilde 2002; Towns 1969; Vaughan 1985). But their history, largely forgotten, goes back much farther. Among Protestants, the impulse to build what today we term megachurches stretches back to the sixteenth century.

A number of inter-related forces created historical amnesia about the predecessors of the modern megachurch. First and foremost, megachurch promoters lived with a sense of manifest destiny - to them, their churches did represent something new, innovative and unprecedented. Newness and innovation have long-possessed an enduring sense of appeal to middle and uppermiddle class Americans - the group to which these pastors wished to appeal (cf. the argument advanced by Schmidt 1995). Additionally, by marketing themselves as a 'new social phenomenon', megachurches received a great deal of media attention. Even though much of the publicity took on a negative tenor, bad publicity is still publicity. The media took the proclamations about the unprecedented nature of megachurches at face value. This stemmed partially from ignorance about religion on the part of the reporter (Buddenbaum 1998); but more importantly, journalism has long obscured historical precedent in favor of novelty (Phillips 1976). 
Megachurches are big. While some attach a threshold to the number of attenders a megachurch contains - 1,500 regular attenders is a popular threshold - it is sufficient to say that these are the very largest of the large (Thumma 1996). According to research analysing the National Congregations Study, the largest 1 percent of Protestant congregations in the United States attracts 1,000 or more attenders (Chaves 2006). But beyond simply being big, megachurches share other characteristics. They come out of the Protestant tradition, they offer a multitude of programmes tailored to people's needs, and they frequently aim to achieve broader cultural importance. While most megachurches in America today espouse a conservative theology, this reflects the fact that the dominant form of Christianity today is evangelical in orientation, rather than an essential connection between conservative theology and very large churches.

Even though megachurches in everything but name have a long history in America, the media did not brand them as a distinctive form of religious organisation until the $1980 \mathrm{os}$. A collective awakening in the media to the presence of large Protestant congregations occurred in and around 1980. During this time the so-called 'church growth' movement began gaining prominence, due in large part to the establishment of the Charles E. Fuller Institute of Evangelism and Church Growth at Fuller Seminary in 1980. This movement promoted marketing-based approaches to church organisation and heralded several signature churches (Willow Creek Community Church and Saddleback Community Church, included) as purveyors of a new kind of church for a new age. Elmer Towns at Liberty University; Stephen Vaughan at Southwestern Baptist Seminary; and C. Peter Wagner and Carl George at Fuller Seminary all occupied central roles in this movement. While causality is difficult to establish, the emphasis on church growth, along with favourable demographic trends, seem to have driven began at similar time of other major shifts happening in Protestant churches. As Mark Chaves points out, since the 1970 and across Protestant denominations people are increasingly found in the largest 1 percent of a denominations' congregations (Chaves 2006). Likewise, Thumma and Travis document a steady increase in very large churches. They estimate in 1970, there were 50 churches with an attendance of more than 1,500 people in the United States; but by 2005, that number had grown to more than 1,200. In Thumma and Travis's words, "while megachurches are not an entirely new phenomenon.... the rapid proliferation of these churches since the 1970s.... is a distinctive social phenomenon" (Thumma 1996: 6). However, we should not confuse increasing prevalence with newness. While megachurches increasingly dot the 
religious landscape in America, we find evidence of similar ecclesiastical forms throughout Protestant history.

\section{$4 \quad$ Early Precedents for the Megachurch}

The early Protestant reformers criticised established forms of ecclesial organisation that emphasised the church building as the primary locus of spiritual activity and contact. John Calvin criticised the Roman Catholic Church for spending large sums of money on opulent buildings, but ignoring the poor. $\mathrm{He}$ advocated for two main functions of the church building: as a place for people to come and hear the Word proclaimed, and as a place to receive the Sacraments, rightly administered (Calvin and Beveridge 1989: Preface). The former of these, preaching, became a central concern in Protestant architecture. Writing in 1577, the Protestant reformer Martin Bucer argues,

From the plans of the most ancient temples, and from the writings of the holy fathers, it is well known that among the ancients the position of the clergy was in the middle of the temples, which were usually round; and from that position divine service was so presented to the people that the things recited could be clearly heard and understood by all who were present.

cited in SPICER 2007: 12

Bucer's sentiments had a clear influence both on how many early Protestants constructed their worship spaces, and on how they conceived of the church. With the Protestant Reformation there was a clear shift towards the importance of individual salvation over and against the Church as the vehicle for salvation. Protestant conceptions of the church building quickly took on a more functional turn - building became places to deliver sermons and sacraments to as many individual believers as possible. More than 400 years later, concerns about seating capacity and sound systems continue to dominate the conversations about Protestant church architecture.

Driven by the sentiments echoed by Bucer and a desire for cultural influence, it did not take long for Protestants to begin imagining what we would later call the megachurch. The earliest example comes from France. The edict of Nantes (1598) granted Protestants in France the right to legally build and organise churches. Already by 1601, Protestants began dreaming big. The Huguenot architect Jacques Perret provides a dramatic example (Perret and de Bry (engr.) 1602). In his 1601 book, Des fortifications et artifices, architecture et 
perspective, he draws up plans for an idealised Protestant Temple, shown in Figure 2.1. It was envisioned to hold nearly 10,00o people on its main floor and included two additional balconies. The preacher stood close to the centre of the nearly square building to maximise the ability of worshippers to hear the sermon. Three levels of ancillary spaces to accommodate secular and religious purposes surrounded the temple. The roof had the characteristic lantern shape of many Protestant Temples, which amplified the speaker's voice (cf. Guicharnaud 2000; Thomson 1995; Westphal 2006).

But Perret's vision encompassed more than a large building. He notes that the auditorium could easily be modified to accommodate town assembly meetings. Roman Catholics, who held sacramental views regarding buildings intended for worship, would have balked at the melding of secular and religious purposes in a sanctuary. Speaking of Perret's willingness to dream of a worship space that could be reconfigured as a secular meeting space, one scholar says, "Nothing could more clearly demonstrate the radicalism of the

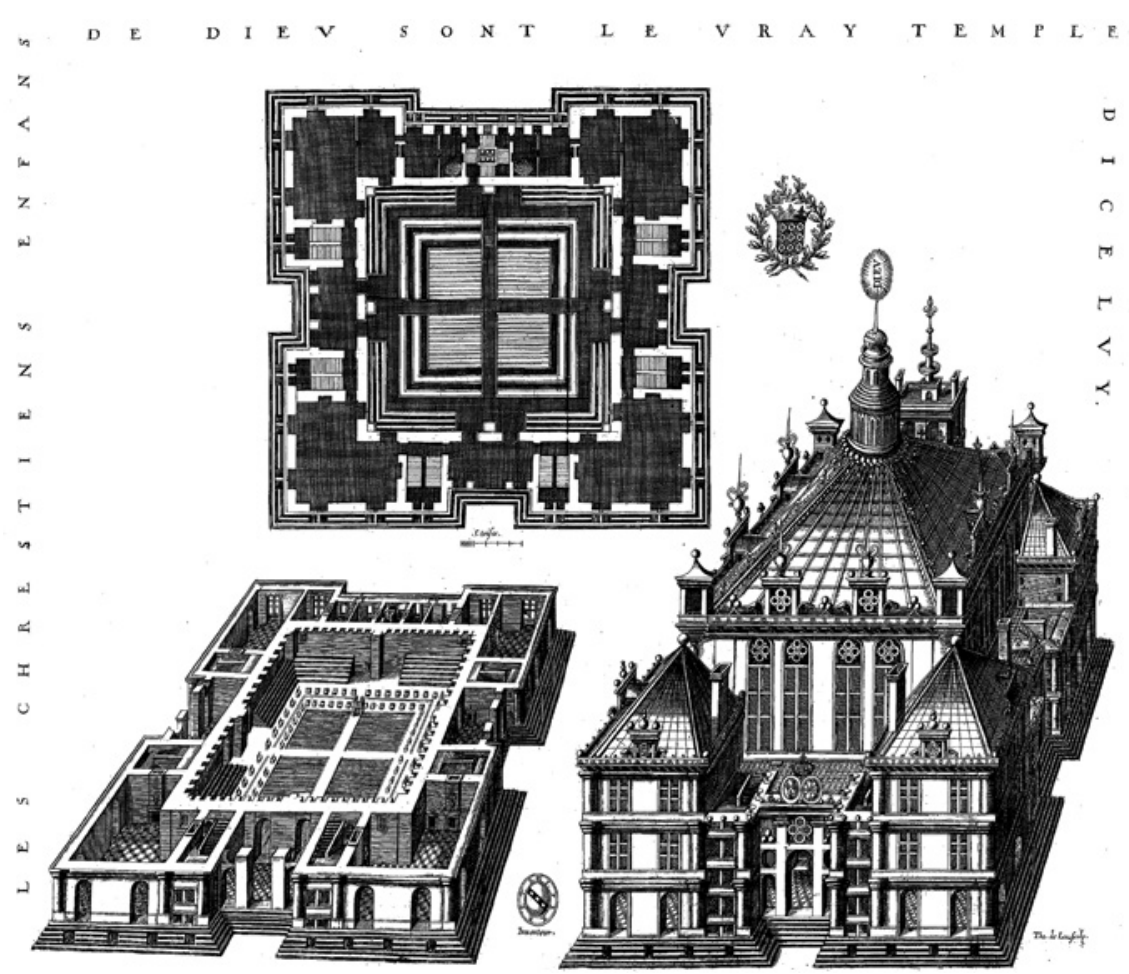

FIGURE 2.1 Jacques Perret's Design for a Grand Temple in his idealised city, 1601 REPRINTED FROM JACQUES PERRET'S BOOK DES FORTIFICATIONS ET ARTIFICES: ARCHITECTURE ET PERSPECTIVE (PARIS, 1601). PUBLIC DOMAIN. 
French Reformers", Perret's vision points to the fundamental rethinking about the place and purpose of the building happening in the Reformation, particularly in France (Hamberg 2002: 36). Written around the outside of Perret's temple we find the slogan, "The Christian children of God are his true temple". The building is still grand and ornate, but it is no longer the locus of God's activity.

On important consequence of a more functional view of the church building is it opened up the possibility that the building could play an important role in the wider political and cultural sphere. Roman Catholic Cathedrals were sacred spaces that held religious relics and consecrated hosts. They were not envisioned as multi-functional spaces for community events. But once the locus of divine activity began to shift to the individual believer, church buildings could also host cultural and community events, which had the further consequence of establishing Protestant church buildings as important anchors in the community.

While Perret's grand Temple was never built, Protestant churches in France adopted similar designs. Many were square or polygonal and had multiple levels from which all attenders could hear the sermon. A 1704 collection of Dutch engravings report the Temple at Quevilly attracted 8,00o worshippers, the one at Dieppe, 6,00o (Thomson 1995: 247-248). The Temple near Paris at Charenton and pictured in Figure 2.2 was perhaps the most famous. It seated several thousand, and was designed by another Hugenot court architect and contemporary of Perret's, Salomon de Bross, in 1623 (Pannier 1911). It is not known if de Brosse and Perret had contact, but striking similarities between their designs exist. These buildings demonstrate an early goal among French Protestants to build large structures to accommodate thousands of worshippers and maximise the ability of individuals to both see and hear the leader perform worship.

\section{5}

\section{Revivalism}

Revivalism was another potent force fueling the creation of large churches. As France began to suppress Protestantism, England became an important site of Protestant activity. Revivalism was an important part of English Protestantism, exemplified by George Whitefield (1714-1770) who played a crucial role in fueling the Protestant impulse to reach the masses using large church buildings. He pioneered a theatrical, engaging form of revival preaching, which attracted crowds of thousands (Stout 1991). Best known for his open-air meetings, Whitefield also commissioned a number of 'Tabernacles' to be constructed throughout England. While originally built as temporary structures, quickly 


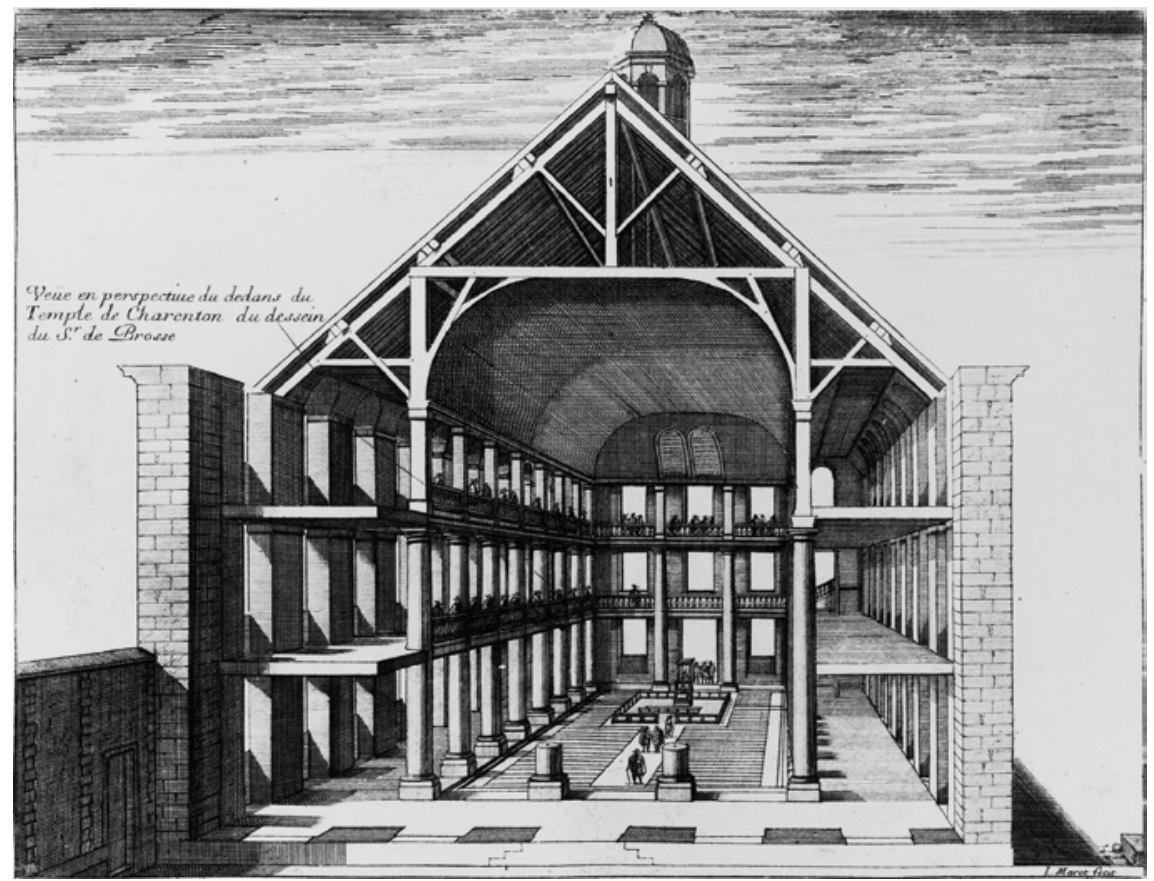

FIGURE 2.2 Temple de Charenton, an orthographic drawing by the architect, Salomon de Brosse, c.1623

USED WITH PERMISSION FROM THE COURTAULD INSTITUTE OF ART

stone replaced the wooden buildings. Whitefield did not name his buildings 'churches' to avoid competition with the Church of England. The name also evoked images of the tabernacle used by the Israelites during their wanderings in the desert (cf. Exodus 25:25) and shared historical continuity with Scottish, Dutch and French Reformed groups (Spicer 2007). Two large Tabernacles, both accommodating several thousand worshippers, made their home in London the Moorsfields Tabernacle, built in the early 1740 s and the Tottenham Court Tabernacle built in the 1750s. These Tabernacles had the characteristic squaredesign and 'lantern-shaped' roof, as opposed to the more traditional long nave and recessed altar of many Anglican churches. This design amplified the speaker's voice and enabled seating in multiple levels around the speaker.

The famous English non-conformist, Charles Haddon Spurgeon, came closest to encapsulating Perret's vision in bricks and mortar, eventually constructing the largest Protestant church building of his day. In 1853, he arrived in London at the age of nineteen to assume the pulpit of Park Street Baptist Church. His popular preaching attracted huge crowds and by 1861 he successfully oversaw the building of the Metropolitan Tabernacle, with room for 6,ooo 


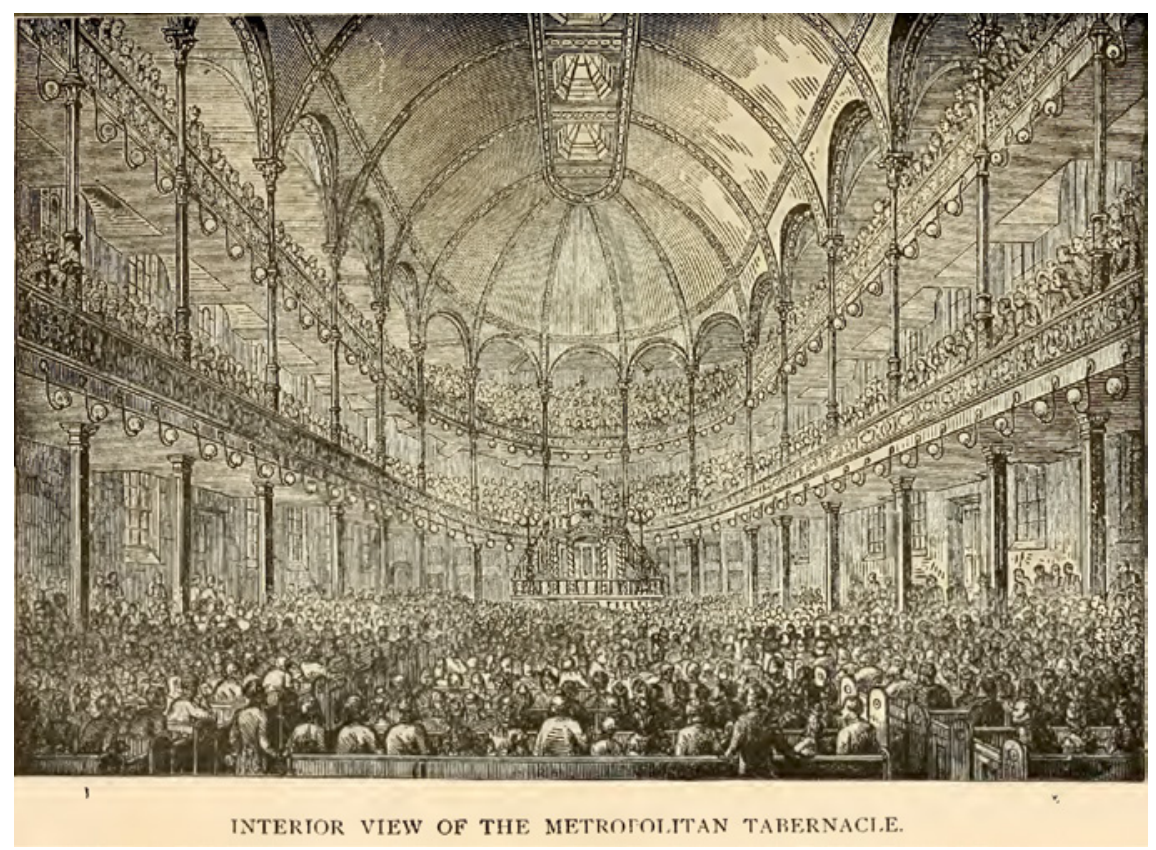

FIGURE 2.3 The interior of the Metropolitan Tabernacle, London, England, 1864 REPRINTED FROM CHARLES HADDON SPURGEON'S BOOK THE METROPOLITAN TABERNACLE PULPIT (LONDON, 1864). PUBLIC DOMAIN

listeners (the church held multiple Sunday and midweek services). Figure 2.3 shows the interior of the original building. In continuity with earlier Protestant architecture - compare with the Temple at Charenton in Figure 2.2 - this structure maximised the ability of the audience to hear the preacher. Spurgeon's church did not merely serve as a place to hear preaching. It housed a huge Sunday School, a preacher's college, a popular annual conference, an orphanage and an alms house. One hundred years later - which demonstrates the important place of Spurgeon in the American evangelical imagination a leading fundamentalist journal, The Moody Bible Institute Monthly, held up Spurgeon's church as an important exemplar for modern Protestant churches to emulate, a point to which I will return below.

\section{The Institutional Church}

Developments in the United States mirrored those in Europe. From very early on, American churchmen looked to Europe for their inspiration. Take the 
Second Great Awakening revivalist, Charles Grandison Finney. In 1836, shortly after renovating the Chatham Theater in New York into a church building, he purpose built a new structure to house the Broadway Tabernacle. It bore a striking resemblance to the 'new' megachurches of the 1980s. Many considered Broadway Tabernacle one of the most influential congregations of nineteenth century America. It seated 2,400, but could accommodate 4,000 (Loveland and Wheeler 2003:38). As Figure 2.4 shows, it featured a central rotunda and a small stage, again emphasising the importance of preaching. It did not serve merely as a place of worship. The congregation rented the sanctuary during the week for various cultural performances; it hosted contemporary debates on women's rights, abolition, and prohibition; and the building housed an extensive ministry to the poor (Nichols and Chalmers 1940). This figure depicts the Tabernacle being used for the distribution of the American Art Union Prizes, again showcasing how from early on in America, using a church building to host highcultural, and notably secular events, had an accepted place.

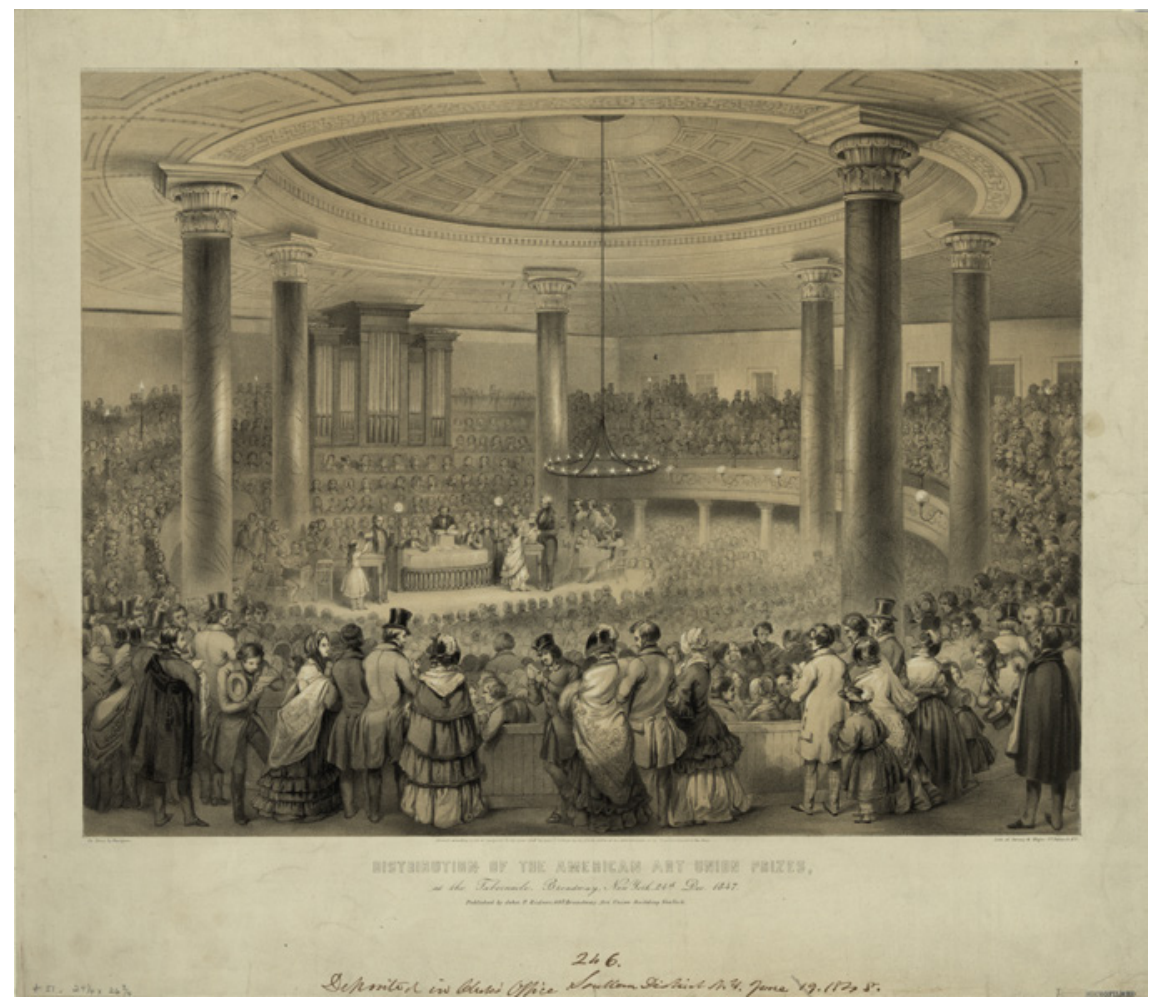

FIGURE 2.4 The interior of the Broadway Tabernacle, New York, NY, 1848 LIBRARY OF CONGRESS. NO KNOW RESTRICTIONS ON PUBLICATION 
The Baptist Temple, built in 1891 in Philadelphia, PA, provides another clear example of the late-twentieth-century megachurch in nineteenth century garb. Standing as a leading exemplar of the Institutional Church Movement and seating at least 3,000 (and perhaps as many as 4,500) the church "combined the auditorium church form and multipurpose facility, enabling them to appeal to the urban elite while at the same time fulfilling a commitment, inherited from the revivalists, to promote moral reform and to evangelise the masses" (Loveland and Wheeler 2003: 38). The Temple boasted a college; one of the best-equipped gymnasiums in Philadelphia; a nearby cricket field and baseball diamond; an affiliated Hospital (to which the Sunday services were broadcast over special speaking tubes); a separate 'Young People's Church', which met in the basement and could accommodate 2,00o; a large banquet facility; and regular concerts, lectures, debates, and readings in its main sanctuary (Burr 1905). As Loveland and Wheeler (2003: 79) note, "The church's founder, Russel H. Cornwell, justified the Temple's sponsorship of 'entertainments' on the grounds that the church should use 'any reasonable means to influence men for good"'.

Early twentieth century church building manuals demonstrate that structures like the Baptist Temple occupied a solid place in Protestant thinking about church organisation. A 1928 manual remarks that "the church has passed beyond the experimental stage in gymnasium work", and, "Bowling alleys have been found very popular. Some churches have difficulty in finding sufficient hours to schedule the alleys" (Conover 1928:141, 143). Even planning for cutting edge communication technology enters the discussion, "A picture booth for a moving picture machine and stereopticon must be considered when planning the parish hall or gymnasium. Several rooms should be equipped with shades so that they may be darkened during the daytime. Provide convenient storage space of the visualization equipment" (Conover 1928: 144). In 1948, another manual states, "Swimming is an increasingly popular form of recreation. In one institutional church in a crowded city section, the total attendance in the swimming pool in one week was 1400" (Conover 1948: 131). Of core importance to churches was the religious education and socialisation of children. This pervades much of the literature at the time, "The Church does not wish to or need to compete with either the theater or the public schools, but the Church has successfully used and adapted other techniques learned from secular education" (Conover 1948: 132). At the 1893 World's Fair in Chicago, a model of the winning Sunday school design from an international competition was constructed. Another shows floorplans of several church Sunday schools, which could accommodate several hundred children in large-group and graded space (Lawrance 1911). Many churches had separate spaces for youth groups and 
youth churches, demonstrating that ministry targeted at young people as a distinct demographic predates the youth ministries of the post-WWII era.

And while more formal Gothic designs became more popular after WWI, Protestants continued to build large worship spaces that maximised the ability of participants to hear and see the drama unfolding on the stage. The Angelus Temple in Los Angeles, CA stands as perhaps the finest witness to the continuing attraction of the huge, multipurpose church building to Protestants. The Temple housed prayer rooms, broadcast facilities and venues from which to run social-service agencies. The desire to reach the masses with the gospel message and to provide a mission outpost to influence the broader society stood behind the Temple's founder Aimee Semple McPherson (Sutton 2007). The sanctuary, built in 1923, is pictured in Figure 2.5. Angelus Temple continued one of the dominant forms of Protestant sanctuary design - a large,

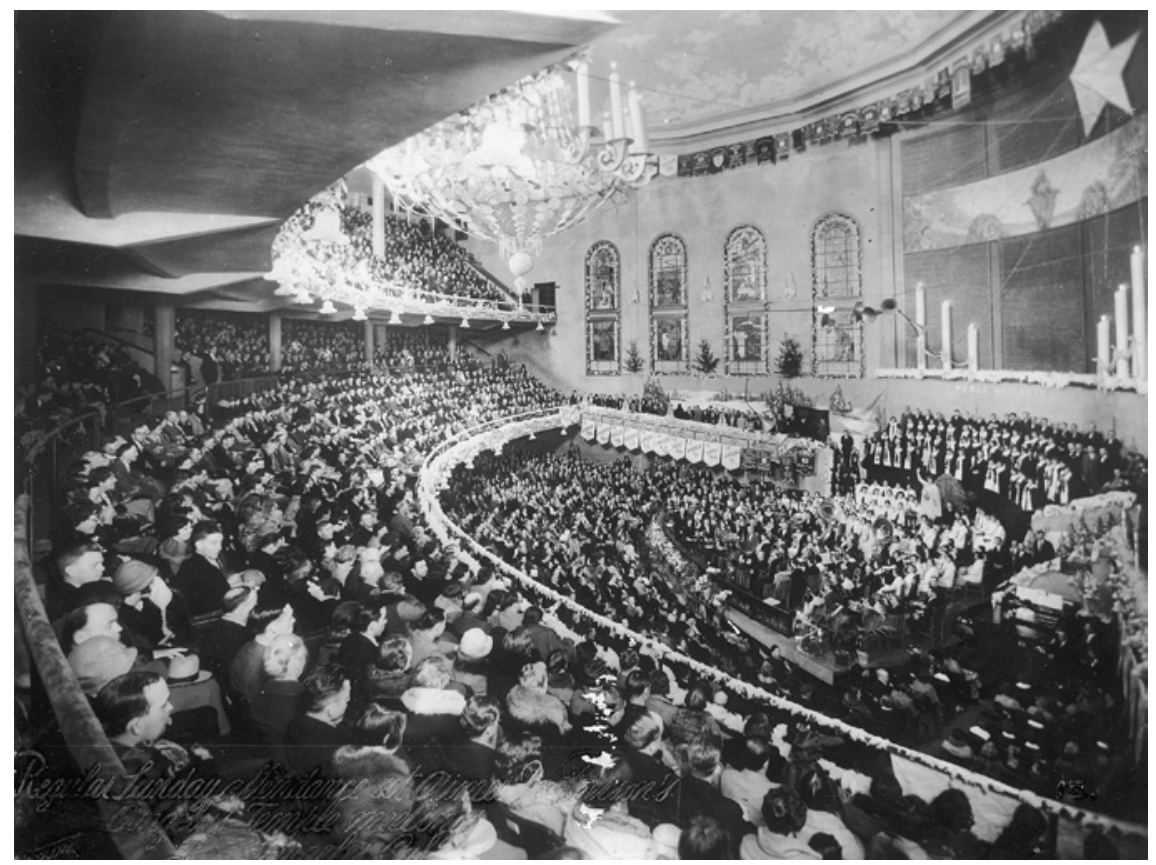

FIgure 2.5 The interior of the Angelus Temple, Los Angeles, c.1930 INTERNATIONAL CHURCH OF THE FOUR SQUARE GOSPEL, HERITAGE DIVISION, USED WITH PERMISSION 
multi-galleried worship space to accommodate thousands that still maintains an intimate focus on the stage.

A clear ecclesiological vision anchored Angelus Temple and other similar congregations. Historical sources document the enduring evangelical concern for 'mass evangelism' - reaching as many people, by whatever means possible, with the gospel message of salvation in Jesus Christ. Beyond simply 'saving souls', mass evangelism was also motivated by the desire to bring about the redemption of American culture, which many evangelicals felt was slipping into chaos. A commitment to mass evangelism, facilitated by a typically more congregational - (as opposed to denominational) - centred polity, led evangelicals to gravitate towards building big meeting spaces, which allowed a large number of people to gather to hear a message in a relatively anonymous setting. They stressed the importance of using of contemporary forms of music and communication to maintain relevance, and they targeted programmes and services to expressed needs. Not all evangelicals embraced mass-evangelism, nor did they uniformly endorse the creation of large, contemporary, needsoriented churches, but mass-evangelism, building large, visible churches, and using a variety of 'attractions' to bring people to the congregation formed a dominant refrain in American Protestantism from at least the mid-nineteenth century onwards, more than 100 years before Willow Creek, Saddleback and its contemporaries appeared on the scene.

The influential Christian social commentator Josiah Strong, whose popularity was only eclipsed by Harriet Beecher Stowe, gives voice to a vision of the church whose marching orders are to 'save souls' and to reverse the moral decay of America through the healthy spiritual and physical growth of adults, children and families (Utzinger 2006:13). In 1893, Strong wrote what could easily have come from a modern church marketing manual,

The question then becomes this: Will the church enlarge her conceptions and activities to the wide measure of her mission and apply the principles of the Gospel to the entire life of each community? Here is the opportunity of the ages for her to gain a commanding influence over the lives of the multitude and fashion the unfolding civilization of the future.

STRONG 1893: 241

Strong, like many others of his day, realised that the centre of gravity of American culture was rapidly shifting to large cities. One challenge was the city often conjured negative images in the imagination of nineteenth century evangelicals (Utzinger 2006: 15-17). Even the prominent Chicago urban revivalist 
Dwight L. Moody had a dark view of the rapidly expanding urban areas of the United States: "The gulf between the church and the masses is growing deeper, wider, and darker every hour" (cited in Strong 1893: 204). But Strong criticised evangelicals for their fear of the city. He viewed the rise of urban para-church ministries like the YMCA/YWCA as indicative of the local church's failure to develop an effective strategy to reach the masses (Strong 1893: 238). Billy Sunday, a prominent American Presbyterian revivalist, controversial and theatrical in style, argued along similar lines:

Every preacher is striving to get the multitude to come to church. If not mass evangelism, then why church mass meetings? In sport we appeal to the masses, in baseball, football, prize-fights, theaters.... The Church will never reach the spiritual position held fifteen years ago until it returns to mass evangelism.

SUNDAY 1933

Accompanying Sunday's comments in the Moody Bible Institute Monthly, another author remarks, "Where the revival, or 'mass evangelism', is discounted by pastor or church.... this results in a cold church formalism which will preclude any kind of evangelism or spiritual religion" (Benson 1933). These quotations echo the chorus of revivalism, a constant refrain throughout nineteenth and early twentieth century American evangelical religion. Here the refrain of revivalism urged evangelicals to see the city as an opportunity for outreach and expansion. The church represented the key institution in this clarion call to reach the cities for Christ.

Dwight L. Moody spent several years in London where he attended the Metropolitan Tabernacle. Spurgeon's church left a deep impression on Moody and exerted an important influence on fundamentalist ecclesiology. In a 1934 article in the Moody Bible Institute Monthly commemorating the centenary of Spurgeon's birth, Rev. W.H. Hockmann extols the ministry of the Metropolitan Tabernacle,

The Tabernacle has been a bee-hive of activity. Overflowing in all directions, not less than thirty centers of Christian ministry were established in different parts of the London area, with some eight thousand children enrolled in various Sunday Schools. A colportage association was formed [for the distribution of tracts and religious materials], alms houses sustained, orphanages for both boys and girls established and the world renowned Pastors College brought into being. Never did the crowds of eager listeners cease to gather at the Tabernacle doors long before the hours for Sunday services. 
Yet in the midst of this popularity:

No man was keener to detect its [modernism's] subtle sophistries, or sense its deadly perils. While his particular forte was evangelism.... nevertheless he waged a valiant and uncompromising warfare [with modernism].... The Metropolitan pulpit never ceased to thunder against compromise with evil, or unbelief or modern thought.

HOCKMANN 1934: 446-447

This article leaves little doubt that the eighteenth century emphasis on reaching the masses remained alive and well in the early part of the twentieth century. Seventy-five years later, Spurgeon's 'megachurch' continued to occupy an important place in the evangelical Protestant imaginary.

Temple Baptist Church, in the quintessential American boomtown, Detroit, MI, exemplifies the strong connections between revivalism and the construction of large, elaborate churches. By 1937, the church had moved into a 5,000seat sanctuary, which was filled to capacity by their pastor, the famous Texas revivalist J. Frank Norris. With 5,00o people in attendance at Sunday school in 1955, many considered it the largest church in America (Towns 1969). After relocating to the Detroit suburbs in 1968, they built a 4,500 seat-sanctuary. Of this structure, one admirer remarked, "The four million dollar building is a testimony to the desire on the part of the people to honor God with the very best.... The carpeted aisles and blue velvet seats give an atmosphere of luxury". But as their long-time pastor, Dr. G.B. Vick pointed out (he shared the pulpit with Norris, who split his time between Temple Baptist and the huge First Baptist in Dallas, TX), the luxurious surroundings do not indicate a movement away from their simple, revivalist roots, "If this church gets too fancy, I'll sprinkle sawdust down the aisle and remind the folks that this is an evangelistic tabernacle" (both quotations are from Towns 1969: 84-85). Vick's remarks remind us that large evangelical churches of the early 1970 continued to invoke the legacy of revivalism and mass evangelism as central components of their identity, all the while constructing buildings that appealed to middle class tastes and sensibilities.

A move to reach the urban masses raised the issue of the degree to which cultural accommodation should occur within churches. Leaders tempered the focus on mass evangelism by concerns about apostasy - churches must not attempt popularity without proper theological integrity. A letter in response to Billy Sunday's call to mass-evangelism article complained, "The argument about mass-appeal of sports, theatres, and politics, is much out of place when applied to religion. Those things have to do with the carnal and physic, not the spiritual" (Sloan 1934). Some worried that mass evangelism and using popular 
methods to appeal to the masses would cause the church to lose its core beliefs, a trap into which so-called liberal or modernist churches had fallen. In spite of these concerns, evangelicals remained convinced that firm conviction could overcome any of the inherent problems with appealing to the masses. The editor of Moody Monthly remarked, "There is still something to be said for mass evangelism, although like many other things it suffers from 'misuse'. The appeal to the 'carnal and physic' is the common appeal of the gospel, and therein it demonstrates its power...." (Sloan 1934). In an article about church publicity, the managing editor of a Christian magazine writes:

The church needs promotion. We need to forward our work by means of publicity. It is vitally necessary for us to adapt modern methods to our advertising program. Adapting modern methods of promotion does not mean that we must be modernistic in doctrine. We can apply sane, up-to-the-minute promotional principles and suggestions, and keep our message sound and evangelical. The primary purpose of the church is to proclaim the message of God's grace and win people to a saving knowledge of Jesus Christ. In order to do this it is necessary to utilize every means at our disposal.

ENGSTROM 1945

Fears about cultural accommodation leading to theological apostasy had long held back many evangelicals from ministry to the urban masses. But a pragmatic appeal to doing whatever it takes to win souls, coupled with separating cultural relevance from theological integrity, remained an important counter argument throughout the twentieth century. In 1969, Dr. Dallas Billington, pastor of the Akron Baptist Temple, with an average Sunday school attendance of 5,762 , demonstrated the continuing appeal of this logic, "Our aim is to win a soul, not false advertising. We will do anything possible to get people to attend, and present the gospel" (Towns 1969).

The end of the Second World War brought with it the prospect of millions of soldiers returning to settle into families, homes, and churches. Suburbs experienced explosive growth, the government poured money into building thousands of miles of highways linking residential communities to factories and other employment centres, the cost of owning and operating a car dropped considerably, and large retail shopping centres began to dot the suburban 
landscape. By 1955, Life magazine reported that $\$ 750$ million worth of church building construction had begun that year ( $\$ 6.6$ billion in 2014 dollars); Denver, CO alone saw the birth of 45 new congregations (Staff Writers 1955). A writer in Moody Monthly, born by patriotism and post-war optimism gave evangelicals their marching orders:

The.... guarantee that our flag may not lose its meaning is to win America for Christ and the Church.... Christians must begin to invite the young and old to church.... Every Christian must get out and touch American life with Christ's saving power if the millions of unchurched children, young people, and adults of our nation are to be won.

HANSON 1945: 274

A buoyant economy and an exploding urban population meant new churches, some of them very large, began to pop up everywhere. Elmer Towns, who from 1969 to 1974, produced a list of the ten largest Sunday schools in America, documented very large Baptist churches in Hollywood, FL, Riverdale, MD, Akron, OH, Hammond, IN, Denver, CO, and Van Nuys, CA (Towns 1969, 1972, 1973, 1974). Because of the explosion in congregation building during this period, it was easy to mistake the sudden appearance of large congregations across the United States as the birth of a new kind of institution. However, the bulk of the evidence presented here demonstrates that the megachurch enjoys a long historical precedent among Protestants. The eighteenth, nineteenth, and early twentieth centuries gave birth to a number of large, multipurpose churches, often built around a popular preacher. These congregations employed the latest technology to reach as many people using all available means. The cultural fuel for the creation of these kinds of churches came primarily from a desire to reach the 'unchurched' with the salvation message, to keep society from falling away from its Christian foundations, and, ultimately, to redeem the culture for Christ. The rapid urban and suburban expansion of the United States, which had continued apace since the early eighteenth century and exploded after WWII, provided the fuel for these expansionist dreams.

\section{$9 \quad$ All Things Mega}

The 1970 and 1980 s brought the right mix of factors to put very large, Protestant congregations on the broader cultural stage. But how did they get branded specifically as megachurches? And, what did that branding imply about these organisations? A series of other 'mega' institutions provided the narrative 
framework on which the media repackaged the large Protestant, institutional church. U.S. atomic scientists popularised the attachment of 'mega' at whim to other words. By the mid-1940s, they talked of megabucks (one million dollars) to refer to the enormous cost of nuclear facilities; they spoke of atomic weapons with megaton destructive capacity (a megaton is the equivalent explosive force of one million tons of dynamite), leading to megadeath (one million deaths). ${ }^{2}$ The media caught onto this usage in the 1950s (Amrine 1951; Colby 1951; Staff Writers 1952). Mega began to appear appended to other words shortly thereafter (Alsop and Alsop 1953).

Mega begins to attach itself to institutions - always with negative connotations - in the 1970s. 'Megacorporation' emerges as one of the first examples (Kirgis 1970). A later New York Times writer laments the corporate sponsorship of the arts by 'MegaOil Inc' (Rockwell 1982). The most relevant for this project is the attachment of mega to shopping mall to produce the 'megamall', which appears first in the mid-1970s (Maxa 1975). The megamall provided the framework upon which to fabricate the megachurch. Megamalls fit within a larger trend of the rapid increase of large regional shopping centres from 1950 onward. From 1955 to 1980 , the number of large regional malls increased from about 10 to 1,250 (Chaves 2007). The media responded to this expansion with a barrage of vitriolic attacks. "They loom like monsters next to the freeways of Orange County: South Coast Plaza, the county's mega-mall, and her 14 lesser sisters", wrote one Los Angeles journalist (Rivera 1983). The Washington Post cynically editorialised on a mall in Jefferson County, CO, "To the swelling strains of 'Oh, What a Beautiful Morning', on the Muzak, a new day was breaking at Southwest Plaza, an enormous pentagonal shopping mall that floats above a vast sea of suburban homes like the battleship New Jersey at a convention of canoes" (Reid 1985). An architect also in the Post wrote, "Who can deny the efficacy of the modern mega-mall.... ? Yet rarely are such architecture behemoths truly lovable, either as works of art or as humane, charm-filled places" (Lewis 1992). The New York Times also joined the refrain,

Malls are dinosaurs, ungainly, vulnerable, completely out of scope with their environment... Malls are symbolic of undisciplined American consumption, showrooms for planned obsolescence.... They are a flagrant

2 The prefix 'mega' did not enter popular usage until Thomas Edison in 1878 invented the megaphone (lit. large voice). It had earlier, more technical, usage in megalithic (c.1839) and megaopolis (c.1832) and in megalomaniac (c.189o). The term was also used extensively in science. Think of the electronics term, megahertz (one million cycles per second c. 1941) and, later, megabits (one million bits of information c. 1957). These dates come from Harper, D., The Online Etymology Dictionary, http://www.etymonline.com. Accessed 5/9/18. 
violation of the conservation ethic that is emerging as key response to the energy crisis. Malls denigrate the character and quality of life in the neighborhoods in which they exist.... Malls defy the test of common sense. The values that sustain them have been challenged. They have no justification, no purpose, other than those of their makers.

NEILL 1979

Throughout the 1980s and 1990s, critics blast the megamall for embodying the 'un-American' values of anonymity, greed, and consumption.

Commentators cry foul, when all of sudden, American Protestantism, a central - but hotly contested - locus of 'American' values, appears wrapped in megamall packaging. Even though megachurches in everything but name have a long history in U.S., the media did not brand them as a distinctive form of religious organisation until the 198 os. A collective awakening in the media to the presence of large Protestant congregations occurred in and around 1983, concurrent with the rise of the church growth movement. As already mentioned, this movement promoted marketing-based approaches to church organisation and heralded several signature churches (Willow Creek Community Church and Saddleback Community Church, included) as purveyors of a new kind of church for a new age. For all their rhetoric about newness, the church growth movement relied heavily on a strong historical precedent in Protestant ecclesiology and bricks-and-mortar congregations.

The media took the proclamations about the unprecedented nature of these new, conservative, large, and fast-growing congregations at face value and branded these 'new' organisations megachurches. ${ }^{3}$ What was new about megachurches was not so much the institutions themselves. Rather, a detailed examination of how the term emerged in the 1980s and early 1990s in American newspapers reveals how large Protestant churches were situated in previously established (and continuing) debates over megamalls. As with megamall, megachurch carried with it a sinister tinge - megachurches are armies, out to conquer America. Growing concerns about the take-over of American society by evangelical religion fuelled these concerns.

3 Who exactly coined the term is probably lost to history. Already by 1985 , the word had appeared in a dissertation title, see Grantier, R. 1986. Perception: A 'Mega' Church Concept. Master's thesis, Mississippi State University, Mississippi State, MS. Carol Flake, however, in her 1984 book on the subject opts for the term 'Super Church', indicating that megachurch as a term was still relatively new. 
Based on the best available data, the term 'megachurch' appeared for the first time in the Miami Herald on April $3,1983 .{ }^{4}$ The article begins:

As the sun breaks this morning on the most joyful and significant day of the Christian calendar, 12,00o people - roughly the same number who live in St. Augustine - will be drawn here, to sing their hosannas on this one particular spot just up the road from the pretty, pagan delights of the Mai Kai. This is Coral Ridge Presbyterian Church of Fort Lauderdale, measurably the fastest-growing Presbyterian church in the country. It is a temple of superlatives, a huge, 3,200-seat spiritual supermarket built by the hand of man and the grace of God. This is about as far from the little church in the wildwood as you can get. It is mega-church, vigorously, fervently evangelical, and - the Devil beware - it is on the march.

FICHTNER 1983

The article goes on to describe in detail the size of the building, the expensive Italian pipe-organ, the vast array of educational offerings, its publishing and media empire, and the successful 'Evangelism Explosion' programme founded by its senior pastor, James Kennedy. Kennedy, once an aspiring stage performer, tells of arriving at the congregation with a freshly minted degree from Columbia (SC) Seminary in 1959 to a congregation of 45, which soon dwindled to 17. By knocking on doors and encouraging his parishioners to do the same, the church quickly grew to mammoth proportions. It constructed its sanctuary in 1974 at a cost of $\$ 4.25$ million dollars (more than 17 million in 2010 dollars).

This basic tone continues through the next decade. In 1991, Gustav Niebuhr wrote,

'Megachurches' like the 6,ooo-seat Second Baptist Church in Houston TX, led by H. Edwin Young, are gaining popularity across the US. Considered the hottest thing in Protestantism, such churches are primarily designed for a generation unversed in theology, essentially nonsectarian and unsentimental about the old neighborhood church. The Christianity served up at megachurches is mostly conservative and to-the-point, stripped of most of the old hymns, liturgy and denominational dogma that tend to bore the video generation.

NIEBUHR 1991

4 A keyword search was conducted on the America's Newspapers database. This database does not contain all of the newspapers published in the U.S. but it has the largest and most comprehensive electronically-searchable collection. 
Another article from the 1990 edition of the San Antonio Express-News uses more graphic, visceral language. It described the "inevitable" outcome of people shopping for a church is:

.... the 'one-stop church complex', or 'megachurch' that, like a combination hot and cold spiritual salad bar, provides a 'total environment under a single sacred canopy'. But what happens when the canopy turns into a sealed bubble meant to block out every secular germ that might otherwise infect the spiritual purity of those inside? Will they, like little albino cave fish, lose the use of their eyes? Or will their survival, like the child born without a functioning immune system, hinge upon the total sterility of their environment?

Staff Writers 1990

As with the debates about megamalls, the themes of an impersonal corporate takeover of a once local organisation loom large. There is an outcry against dumbing down the content of religion in favour of attracting adherents. The megamall set the narrative framework into which large, evangelical Protestant churches were dropped, despite the fact that these types of congregations had been around for a very long time.

The media does not bear singular responsibility for the historical amnesia about the megachurch. Many insiders share equal complicity. By the 1970s, a group of large-church pastors including James Kennedy, Bill Hybels, and Rick Warren already had a well-developed sense that their form of congregational organisation lacked precedence. And while megachurch promoters went out of their way to dispel media stereotypes of these churches, they did not argue with the idea that their institutions lacked historical continuity. As I cited early on in this paper, Bill Hybels was convinced he was doing something new that was specifically tailor to a new cultural reality. Why did Hybels and many others of his generation of large church pastors claim their movement lacked precedent? Simply put, novelty carries enormous value in American culture; a new social phenomenon sells better than the continuation of a long historical trend.

However, in spite of media accounts and the proclamations megachurch promoters, big churches offering a wide array of services and focused on attracting adherents was not something new. Protestants had long built large, multi-purpose buildings that offered a host of religious and worldly services under one roof. The 1970s and 1980s brought the right mix of factors to put these churches on the broader cultural stage. Suburban development pressures and fears 
about impersonal corporations taking over American life had already surfaced in connection with large retail shopping malls. When journalists caught wind of leaders of large, growing Protestant churches proclaiming that the melding of retail marketing strategy with the church would create a new, superior form of church, they paid attention. Few stopped and recognised the historical precedent for the megachurch, which, as a Protestant impulse, goes back to the beginnings of the Reformation in Europe.

10

\section{Conclusion}

At the beginning of the 1980 s, reporters and pastors cemented the image of the megachurch as a new, made-in-the-UsA religious institution. But those who see the megachurch as a modern invention, without a long history, are wrong. Protestants had long built large, multi-purpose buildings that housed a host of religious and worldly services under one roof. Few have stopped to recognise the strong historical precedent for what we now term the megachurch. As a Protestant impulse, the megachurch goes back to the beginnings of the Reformation in Europe.

During the 1980s and 9os, middle class America experienced important social-structural shifts that privileged large churches. In particular, the increase in female labour force participation put a time squeeze on the discretionary time enjoyed by families, and made large, well-staffed congregations more popular (Chaves 2006). Nevertheless, while changing family dynamics and favourable development processes aided the popularity of megachurches in America, we make a mistake if we confuse their increase in prevalence with them constituting "a new social form". They are not a new religious phenomenon, let alone one of "the most important developments of modern Christian history". They represent an enduring model of ecclesial organisation in Protestantism, stretching back to the early seventeenth century. Hopefully, situating megachurches in their proper historical context will avoid starry-eyed optimism at the wonder of these spectacular congregations, and curmudgeonly critiques of them as flash-in-the-pan organisations with little staying power.

\section{References}

Allitt, P. 2003. Religion in America Since 1945: A History. New York: Columbia University Press. 
Alsop, J. and Alsop, S. 1953. "A New Jargon for This Atomic Age." The Washington Post. 22 June: 6.

Amrine, M. 1951. “'Megabucks' for What's 'Hot.” New York Times. 22 April: 186.

Benson, C. 1933. "Our Monthly Potpourri: Increasing Leisure." Moody Bible Institute Monthly. 34:2, 68-69.

Buddenbaum, J.M. 1998. Reporting News About Religion: An Introduction for Journalists. Ames, IA: Iowa State University Press.

Burr, A.R. 1905. Russell H. Conwell: Founder of the Institutional Church in America: The Work and the Man. Philadelphia, PA: J.C. Winston Company.

Calvin, J. and Beveridge, H. 1989. Institutes of the Christian Religion. Grand Rapids, MI: William B. Eerdmans.

Chandler, R. 1989. "Test-Marketing the Gospel - A Consumer Survey Helped Design Willow Creek Church for Its 'Customers.' San Francisco Chronicle. 24 December: Sunday Punch: 3 .

Chaves, M. 2006. "All Creatures Great and Small: Megachurches in Context." Review of Religious Research. 47:4, 329-346.

Chaves, M.A. 2007. "Why Megachurches?" in Invited inaugural lecture at the William Form and Joan Huber Symposium Series, Department of Sociology, The Ohio State University. Columbus, $\mathrm{OH}$ : Ohio State University.

Colby, F. 1951. "Take My Word For It." Los Angeles Times. 19 July: A5.

Conover, E.M. 1928. Building the House of God. New York: The Methodist Book Concern.

Conover, E.M. 1948. The Church Builder. New York: The Interdenominational Bureau of Architecture.

Engstrom, T. 1945. "Publicizing Your Church." Moody Bible Institute Monthly. 45:5, 272, 294-295.

Fichtner, M. 1983. "Like a Mighty Army.... Move the Church of God'." The Miami Herald. 3 April: $1 \mathrm{G}$.

Flake, C. 1984. Redemptorama: Culture, Politics, and the New Evangelicalism. New York, NY: Penguin Books.

Guicharnaud, H. 200o. "Approche de l'Architecture Des Temples Protestants Construits En France Avant La Révocation." Études Théologiques et Religieuses. 75:4, 477-504.

Hamberg, P.G. 2002. Temples for Protestants : Studies in the Architectural Milieu of the Rarly Reformed Church and of the Lutheran Church. Gothenburg, Sweden: Gothenburg University Press.

Hanson, O.C. 1945. "Are They Dying in Vain?" Moody Bible Institute Monthly. 45:5, 273$274,284-285$.

Hockmann, W.H. 1934. “Spurgeon, a Prince among Men." Moody Bible Institute Monthly. 34:10, $445^{-447 .}$ 
Kilde, J.H. 2002. When Church Became Theatre: The Transformation of Evangelical Architecture and Worship in Nineteenth-Century America. Oxford: Oxford University Press.

Kirgis, F.L. 1970. "Nations' Self-Interest Leaves World Court on the Sidelines.” The Washington Post, 9 August: B2.

Lawrance, M. 1911. Housing the Sunday School. Boston, MA: Pilgrim Press.

Lewis, R. 1992. "Shaping the City." The Washington Post. 15 February, F29.

Loveland, A.C. and Wheeler O.B. 2003. From Meetinghouse to Megachurch: A Material and Cultural History. Columbia, MO: University of Missouri Press.

Marty, M. 1990. "Minichurch and Megachurch." The Christian Century. 107:28, 919.

Maxa, R. 1975. "The Front Page." The Washington Post, 23 March: 204.

McNair, W. 2009. Unraveling the Mega-Church: True Faith or False Promises? Westport, CT: Praeger.

Neill, P. 1979. "Why Supermall Is Superbad." New York Times, 5 August: CN2o.

Nichols, L.N. and Chalmers, A.K. 1940. History of the Broadway Tabernacle. New Haven, CT: The Tuttle, Morehouse and Taylor Company.

Niebuhr, G. 1991. "Mighty Fortresses: Megachurches Strive to Be All Things to All Parishioners." Wall Street Journal, 13 May: A1.

Niebuhr, G. 1995. “Where Religion Gets a Big Dose of Shopping-Mall Culture." New York Times, 16 April: 1.

Pannier, J. 1911. Un Architecte Français Au Commencement Du 17e Siècle. Paris: Librairie centrale d'art et d'architecture.

Perret, J. and de Bry, J.T. (engr.). 1602. Des Fortifications \& Artifices de Jaqves Perret, Gentilhomme Savoysien. Paris.

Phillips, E.B. 1976. "Novelty Without Change." Journal of Communication. 26:4, 87-92.

Reid, T.R. 1985. "Mall-Adjusted Americans Fuel Amazing Money Machines." The Washington Post. 30 August: A1.

Rivera, N. 1983. "Hold Special Promotions, Go After Byers, Small Stores Organize to Battle Big Centers." Los Angeles Times, 13 December: E1.

Rockwell, J. 1982. "Will True Digital-Sound Records Arrive in 1982?" New York Times. 1 January:15.

Schaller, L.E., 1990. "Megachurch!" Christianity Today. 34:4, 20-24.

Schmidt, L.E. 1995. Consumer Rites: The Buying \& Selling of American Holidays. Princeton, N.J.: Princeton University Press.

Sloan, M.E. 1934. “The Bible and 'Mass Evangelism'." Moody Bible Institute Monthly. 23:5, 220.

Spicer, A. 2007. Calvinist Churches in Early Modern Europe. Manchester and New York: Manchester University Press.

Staff Writers. 1952. "Business Bulletin." Wall Street Journal 18 December: 1. 
Staff Writers. 1955. "An Unprecedented Wave of Religious Observance Sweeps over the U.S." Life: 12.

Staff Writers. 1990. "Baby Boomers Are 'finding' Religion." San Antonio Express-News 30 December: $3 \mathrm{M}$.

Stout, H.S. 1991. The Divine Dramatist: George Whitefield and the Rise of Modern Evangelicalism. Grand Rapids, MI: W.B. Eerdmans.

Strong, J. 1893. The New Era. New York: Baker \& Taylor Company.

Sunday, B. 1933. "Evangelist Sunday on Mass Evangelism." Moody Bible Institute Monthly. 33:2, 51 .

Sutton, M.A. 2007. Aimee Semple McPherson and the Resurrection of Christian America. Cambridge, MA: Harvard University Press.

Thomson, D. 1995. "Protestant Temples in France c. 1566-1623, Etudes Reunies Par Jean Guillaume." edited by J. Guillaume. Centre d'Etudes Superieures de La Renaissance, $245^{-256 .}$

Thumma, S. 1996. Exploring the Megachurch Phenomena: Their Characteristics and Cultural Context. Hartford Institute for Religion Research at Hartford Seminary: http:// hirr.hartsem.edu/bookshelf/thumma_article2.html, accessed 2 April 2014.

Thumma, S. and Travis, D. 2007. Beyond Megachurch Myths: What We Can Learn from America's Largest Churches. San Francisco, CA: Jossey-Bass.

Towns, E.L. 1969. The Ten Largest Sunday Schools and What Makes Them Grow. Grand Rapids, MI: Baker Book House.

Towns, E. 1972. America's Fastest Growing Churches: Why 10 Sunday Schools Are Growing Fast. Nashville, TN: Impact Books.

Towns, E. 1973. Great Soul-Winning Churches. Murfreesboro, TN: Sword of the Lord Publishers.

Towns, E.L. 1974. World's Largest Sunday School. Nashville, TN: Thomas Nelson.

Utzinger, J.M. 2006. Yet Saints Their Watch Are Keeping: Fundamentalists, Modernists, and the Development of Evangelical Ecclesiology, 1887-1937. Macon, GA: Mercer University Press.

Vaughan, J. 1985. The Large Church: A Twentieth-Century Expression of the First-Century Church. Grand Rapids, MI: Baker Book House.

Westphal, Norman. 2006. "La Place Du Temple Dans Un Modele de Ville Protestante: Les Propositions de Jaques Perret Dans Son Traite 'Des Fortifications et Artifices (1601)'”, edited by H. Bust. Bulletin de La Societe de l'Histoire Du Protestantisme En France. 152, 263-374. 